๑). Н. Вадзюк, М. І. Горішний, I. М. Горішний

Тернопільсъкий нащіональний медичний університет ілені І. Я. Горбачевсъкого МОЗ України

\title{
ВЛАСТИВОСТІ НЕРВОВИХ ПРОЦЕСІВ У ДІТЕЙ З РІЗНИМИ ПСИХОТИПАМИ
}

\begin{abstract}
Мета дослідження - встановити взаємозв'язок між психотипом дитини і силою та фуннкціональною рухливістю нервових процесів.

Матеріали та методи. Для визначення психотипу проводили анкетування у 86 дітей віком до 18 років за допомогою опитувальників Вайсбанда та Гуленка. Нервові процеси аналізували за комп'ютерною програмою «Діагност 1М». Статистичну обробку даних проводили методом непараметричної статистики, використовуючи U-тест - критерій Манна - Уїтні.

Результати дослідження та їх обговорення. Встановлено залежність кількості оброблених подразників при вивченні сили нервових процесів у режимі зворотного зв'язку від психотипу дитини ( $<<0,01)$. Зокрема, відмінність $€$ між провідними фуункціями логіки, етики та сенсорики. Найвищий показник кількості переробки інформації в сенсориків $(621,28)$, найнижчий - у логіків $(552,48)$. Також встановлено різницю функціональної рухливості нервових процесів у режимі зворотного зв'язку між логіками та етиками $(p<0,05)$. Зокрема, мінімальний час реакції в логіків менший в 1,6 раза. Залежності реакції на рухомий об'єкт від психотипу виявити не вдалося ( $>>0,05)$.

Висновки. За допомогою опитувальників визначено психологічні типи за Юнгом у 60 респондентів. На базі комп'ютерної програми «Діагност 1М» виміряно силу та фрункціональну рухливість нервових процесів у дітей. Встановлено залежність вищенаведених показників від їх психотипу.
\end{abstract}

Ключові слова: сила нервових процесів; функціональна рухливість нервових процесів; психотип дитини.

\section{СВОЙСТВА НЕРВНЫХ ПРОЦЕССОВ У ДЕТЕЙ С РАЗЛИЧНЫМИ ПСИХОТИПАМИ}

Цель исследования - установить взаимосвязь между психотипом ребенка и силой и функциональной подвижностью нервных процессов.

Материалы и методы. Для определения психотипа проводили анкетирование у 86 детей в возрасте до 18 лет с помощью опросников Вайсбанда и Гуленко. Нервные процессы анализировали по компьютерной программе «Диагност

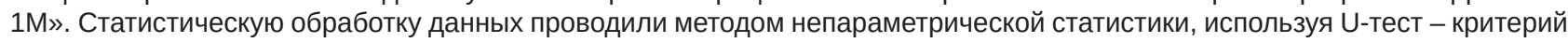
Манна - Уитни.

Результаты исследования и их обсуждение. Установлена зависимость количества обработанных раздражителей при изучении силы нервных процессов в режиме обратной связи от психотипа ребенка $(p<0,01)$. В частности, отличие есть между ведущими функциями логики, этики и сенсорики. Самый высокий показатель количества переработки инсормации у сенсориков $(621,28)$, самый низкий -у логиков $(552,48)$. Также установлено разницу фуункциональной подвижности нервных процессов в режиме обратной связи между логиками и этиками (р<0,05). В частности, минимальное время реакции у логиков меньше в 1,6 раза. Зависимость реакции на движущийся объект от психотипа обнаружить не удалось (р>0,05).

Выводы. С помощью опросников определены психологические типы по Юнгу у 60 респондентов. На базе компьютерной программы «Диагност 1М» измерено силу и функциональную подвижность нервных процессов у детей. Установлена зависимость вышеприведенных показателей от их психотипа.

Ключевые слова: сила нервных процессов; функциональная подвижность нервных процессов; психотип ребёнка

PROPERTIES OF NEURAL PROCESSES IN CHILDREN WITH DIFFERENT PSYCHOTYPES

The aim of the study - to establish the relationship between human psychotype, strength and functional mobility of neural processes.

Materials and Methods. To determine the psychotype, 86 respondents were interviewed using the Weissband and Gulenko questionnaires. The analysis of nerve processes was performed with a computer program "Diagnost 1M". Statistical processing of data was made by the method of nonparametric statistics, establishing $U$ test - Mann-Whitney test.

Results and Discussion. The dependence of the number of stimuli processed in the study of the strength of the nervous processes using the feedback mode of the human psychotype $(p<0.01)$ was established. In particular, the difference is between the leading functions of logic, ethics, and sensory. The highest indicator of the amount of information processing in sensors (621.28), the lowest - in logics (552.48). There was also a difference in functional mobility of nerve processes using the feedback mode between logic and ethics $(p<0.05)$. In particular, the minimum reaction time for logic is less than 1.6 times. No dependency, response to moving object from psychotype was detected $(p>0.05)$.

Conclusions. The questionnaires identified Jung's psychological types in 60 respondents. On the basis of the computer program "Diagnost $1 \mathrm{M}$ " the strength and functional mobility of nervous processes in students were measured. The dependence of the above indicators on the human psychotype was established.

Key words: strength of neural processes; functional mobility of neural processes; human psychotype.

ВСтУП. Першим ученим, який провів ґрунтовні дослідження психіки здорових людей, став Карл Густав Юнг, швейцарський учений, психіатр і психотерапевт. Він роз- робив систему типології особистості, основану на понятті психологічної установки, яка може бути екстравертною або інтравертною, і на переважанні тієї чи іншої психоло- 
гічної фрункції - мислення, відчуття, почуття або інтуїції. Ця типологія була опублікована в його праці «Психологічні типи» у 1921 році [1-3]. К. Г. Юнг визначив чотири типи: думаючий (логічний), відчуваючий (етичний), інтуїтивний, чуттєвий (сенсорний) [3,4]. На основі роботи Юнга «Психологічні типи» американські психологи Ізабелла МайерсБріггс і Кетрін Бріггс розробили власну типологію та на іï основі започаткували науку соціоніку. Вони збільшили кількість психотипів з восьми до шістнадцяти [5].

Кожен індивідуум має переважно генетично детерміновані особливості фрунціонування нервової системи, які визначають відмінності в характері реагування на один і той самий вплив фрізичного та соціального середовищ i, отже, утворюють ґрунт для фрормування поведінки. Російський учений І. П. Павлов, вивчаючи особливості перебігу нервових процесів у людини, виділяв у них три основні властивості: силу, врівноваженість і рухливість [6].

Сила нервових процесів - це здатність нервових клітин зберігати адекватну працездатність при значній напрузі збуджувальних і гальмівних процесів. В її основі лежить вираження в центральній нервовій системі процесів збудження і гальмування. Люди, які мають більш сильну нервову систему, є більш витривалими і стресостійкими [7].

Рухливість нервових процесів свідчить про здатність до швидкого переходу від збудження до гальмування. У людей $з$ більш рухливою нервовою системою відзначається велика гнучкість поведінки, вони швидше пристосовуються до нових умов [8]. Різні поєднання цих характеристик нервових процесів зумовлюють той чи інший тип темпераменту i, деякою мірою, властивості характеру й особистості. Наприклад, сила процесу збудження лежить в основі витривалості, енергійності, працездатності, гарячковості, мужності, хоробрості, активності, сміливості, здатності долати труднощі, ініціативності, схильності до ризику, самостійності, рішучості, наполегливості. Сила гальмування визначає такі властивості: обережність, самовладання, терпіння, скритність, стриманість, холоднокровність.

Проте в доступній нам літературі ми не знайшли зіставлення властивостей нервових процесів у дітей 3 різними психотипами.

МЕТА ДОСЛІДЖЕННЯ - Встановити вЗаємозв'язок між психотипом дитини і силою та функціональною рухливістю нервових процесів.

МАТЕРІАЛИ ТА МЕТОДИ. Діагностика психотипу на сьогодні є однією з найважливіших проблем типології, яка стримує розвиток даної науки і впровадження ії̈ знань у практику. Основними причинами цього є те, що складені численними спеціалістами опитувальники несуть у собі відбиток особистості автора (психометричний есрект), що неможливо усунути ніякими способами. Інші ж методи типування (діагностичне інтерв'ю, контент-аналіз,

Таблиця 1. Розподіл психологічних функцій

\begin{tabular}{|l|c|c||}
\hline Психологічна фрункція & $\begin{array}{c}\text { Кількість } \\
\text { респондентів }\end{array}$ & $\%$ \\
\hline Логіка & 23 & 38,30 \\
\hline Етика & 21 & 35,00 \\
\hline Сенсорика & 7 & 11,60 \\
\hline Інтуїція & 9 & 15,00 \\
\hline
\end{tabular}

спостереження) дають достовірні результати при застосуванні їх підготовленими фрахівцями [1-4]. 3 огляду на це, спеціалісти пропонують комплексний підхід до діагностики з використанням різних методів та зіставленням результатів. Тому методом досліджень психотипу було соціонічне опитування респондентів із застосуванням анкет та описів психотипів за К. Юнгом. В опитуванні взяли участь 86 дітей віком до 18 років. При анкетуванні застосували тест В. Гуленка та тест І. Вайсбанда. У процесі тестування респондент, відповівши на всі запитання, отримує на екрані комп'ютера назву свого психотипу та його опис. У наступному етапі дослідження дітям давали прочитати короткі описи всіх 16 психотипів. Опитані повинні були вибрати 1-2 (або більше) описів, які, на їх думку, їм найбільше підходять. Результати двох анкетувань та ревізії описів психотипів зіставляли між собою. Таким чином, у кожного респондента було, як мінімум, три результати опитування: два - за анкетуванням і одне або більше - за описами психотипів. Якщо результати двох і більше опитувань збігались, вважали, що психотип студента встановлено.

Наступним етапом дослідження стало ознайомлення респондентів з описами 16 психотипів. Вважали, що психотип визначено правильно, якщо 2 з 3 результатів збігались. Таким чином, вдалось правильно визначити психотип у 60 дітей, результатів інших до уваги не брали. Наступним етапом стала діагностика фрункціональної рухливості нервових процесів у режимі зворотного зв'язку за допомогою комп'ютерної програми «Діагност 1М» [9]. Звертали увагу на час виконання тесту, мінімальний час реакції та відсоток помилок. Силу нервових процесів також аналізували в режимі зворотного зв'язку за програмою «Діагност 1М». Критеріями були: кількість оброблених подразників, відсоток помилок, мінімальний час реакції [10]. Далі порівнювали дані про нервові процеси з психотипом респондента. Статистичну обробку даних проводили методом непараметричної статистики, використовували U-тест - критерій Манна - Уїтні.

РЕЗУЛЬТАТИ ДОСЛІДЖЕННЯ ТА ЇХ ОБГОВОРЕНня. Серед 86 дітей у 60 вдалося правильно визначити психотип. Серед них розподіл був таким: 23 (38,30\%) - 3 провідною фрункцією логіки; 21 (35,00 \%) - 3 провідною функцією етики; 7 (11,60 \%) - сенсорики; 9 (15,00 \%) інтуїти (табл. 1).

Силу нервових процесів визначали за допомогою програми «Діагност 1М». Основним критерієм була кількість оброблених подразників за 5 хв. Найвищий показник мали сенсорики $(621,28)$, найнижчий - логіки $(552,48)(p<0,01)$. Етики, відповідно - 609,00, інтуїти 583,50 (табл. 2).

Функціональну рухливість нервових процесів визначали за часом обробки 120 сигналів. Показник у сенсориків (74 с.) був найменшим порівняно з показником у інтуїтів (81 с.) (p<0,05), логіків (76 с.), у етиків (78 с.) (рис. 1).

Таблиця 2. Сила нервових процесів

\begin{tabular}{||l|c||}
\hline \multicolumn{1}{|c|}{ Психологічна фрункція } & $\begin{array}{c}\text { Кількість оброблених } \\
\text { подразників за 5 хв }\end{array}$ \\
\hline Логіка & 552,48 \\
\hline Сенсорика & 621,28 \\
\hline Етика & 609,00 \\
\hline Інтуїція & 583,50 \\
\hline
\end{tabular}




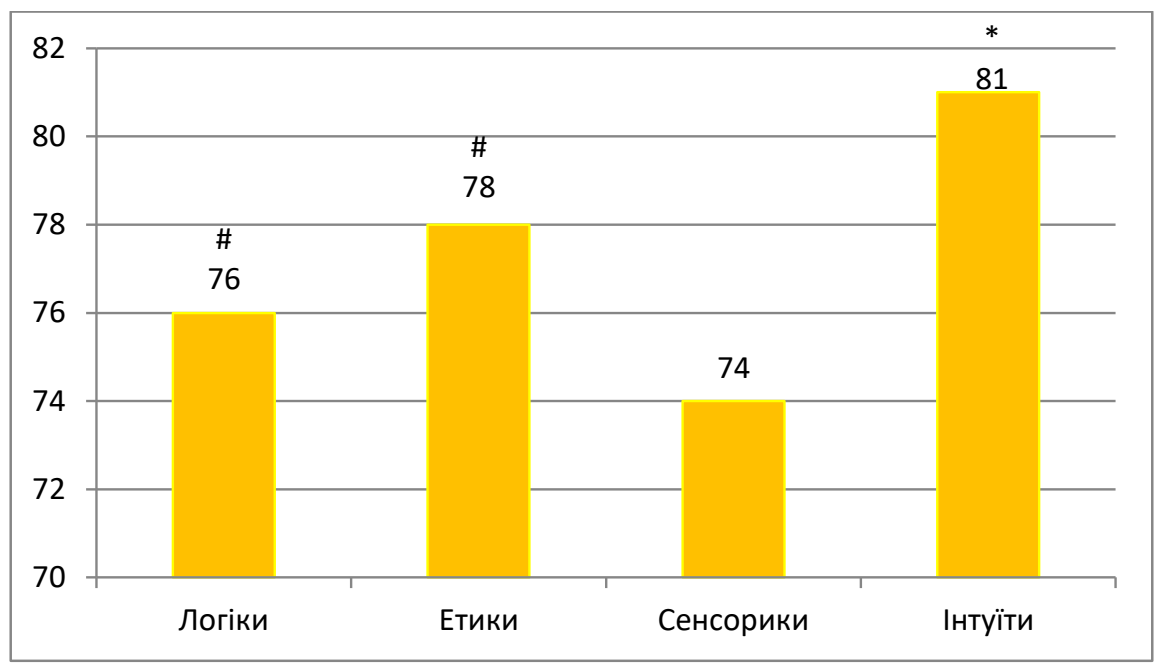

Рис. 1. Функціональна рухливість нервових процесів.

Примітки:

1. * - p<0,05 (U-тест - критерій Манна - Уїтні), відмінності достовірні порівняно з даними в сенсориків.

2. ${ }^{*}$ - $>0,05$, відмінності не достовірні порівняно з даними в сенсориків.

Встановлено залежність мінімальної реакції на подразник при вивченні залежності рухливості нервових процесів від психологічного типу. Мінімальний час реакції в логіків - 74,2 мс, в етиків - 125,4 мс, у сенсориків - 112,14 мс, в інтуїтів - 120 мс. Доведено різницю між показниками логіків та решти психотипів $($ р<0,05) (рис. 2).

Виявлено залежність кількості оброблених подразників при вивченні сили нервових процесів у режимі зворотного зв'язку від психотипу дитини, різницю встановлено між показниками логіків та сенсориків $(\mathrm{p}<0,01)$. Зокрема, відмінність є між провідними срункціями логіки, етики та сенсорики. Найвищий показник кількості переробки інфрормації в сенсориків $(621,28)$, найнижчий - у логіків $(552,48)$. Також встановлено різницю функціональної рухливості нервових процесів у режимі зворотного зв'язку між логіками та етиками $(p<0,05)$. Зокрема, мінімальний час реакції в логіків менший в 1,6 раза. Залежності реакції на рухомий об'єкт від психотипу виявити не вдалося $(p>0,05)$.

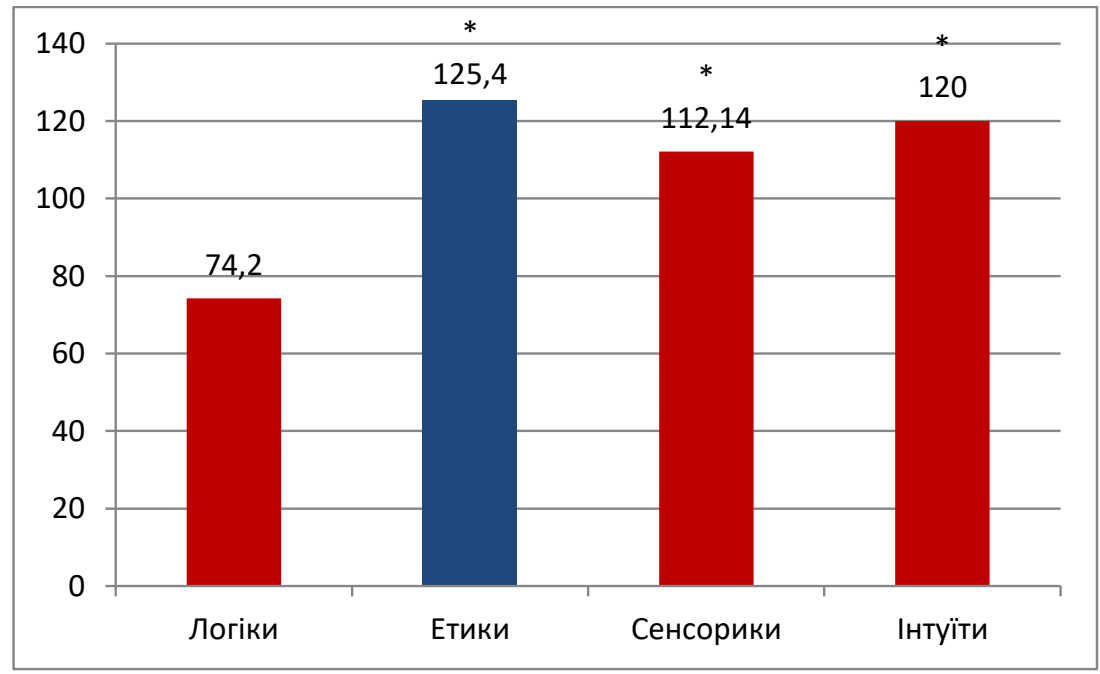

Рис. 2. Функціональна рухливість нервових процесів у різних психотипів.

Примітка. * - p<0,05 (U-тест - критерій Манна - Уїтні), відмінності достовірні порівняно з даними в логіків.

Висновки. 1. Логіки, які становили 38,3 \% усіх респондентів, не здатні аналізувати і реагувати на відчуття, стараються у всьому опиратися на фракти, систематизувати свої знання, обґрунтовують свої ідеї та аргументи. За даними дослідження, вони володіють найменшою силою нервових процесів, проте мають найшвидшу реакцію на подразник, середню функціональну рухливість порівняно з іншими психотипами.

2. Етики становили $35 \%$ серед респондентів, це особи, які передають свої думки через емоції, при спілкуванні більше звертають увагу на тон і паравербальні комунікативні ознаки, ніж на зміст. За даними дослідження, вони 
мають високу силу нервових процесів, проте в них найповільніша реакція на подразник. Функціональна рухливість нервових процесів - вище середнього значення.

3. Сенсорики становили 11,6 \% опитаних дітей, це особи, які досліджують зовнішній світ за допомогою своїх відчуттів, будь-яке абстрактне поняття намагаються перетворити в знайоме або принаймні в гіпотетично відоме, яке він зможе відчути. За даними дослідження, вони мають найвищу силу нервових процесів, проте найнижчу фрункціональну рухливість.

\section{СПИСОК ЛІТЕРАТУРИ}

1. Каганець І. Психологічні аспекти в менеджменті: Типологія Юнга, соціоніка, психоінформатика / І. Каганець. - К. ; Тернопіль : Мандрівець ; Port - Royal, 1997. - 204 с.

2. Прокофьева Т. Н. Соционика. Алгебра и геометрия человеческих взаимоотношений : учеб.-практ. пособ. I Т. Н. Прокофьева. - 2-е изд., стер. - М. : Алмаз, 2005. - 112 с.

3. Прокофьева Т. Н. Соционика для профессионалов. Соционические технологии в педагогике и управлении персоналом / Т. Н. Прокофьева, В. Г. Прокофьев, А. С. Девяткин. - М. : Алмаз, 2008. - 323 с.

4. Гуленко В. В. Структурно-функциональная соционика: Разработка метода комбинаторики полярностей / В. В. Гуленко. - К. : Транспорт України, 1999. - 187 с.

5. Каммероу Дж. Ваш психологический тип и стиль работы / Дж. Каммероу, Н. Баргер, Л. Кирби ; пер. с англ. А. Багрянцевой. - М. : Изд-во Института Психотерапии, 2001. - 224 с.

6. Типи вищої нервової діяльності [Електронний ресурс]. - Режим доступу : https://stud.com.ua/26963/meditsina/
4. Інтуїтами виявились $15 \%$ респондентів, це особи, не здатні помічати об'єктивно реальних речей, інсрормацію зазвичай обробляють підсвідомо, відразу видаючи результат. Швидко вловлюють суть справи, їм властивий інтелектуальний снобізм. За даними дослідження нервових процесів, інтуїти мають низьку силу, проте найвищу фрункціональну рухливість, швидко реагують на подразники.

ПЕРСПЕКТИВИ ПОДАЛЬШИХ ДОСЛІДЖЕНЬ. Дана тема $є$ малодослідженою, тому містить велику площину для подальших досліджень, її вивчення буде продовжено.

tipi_vischoyi_nervovoyi_diyalnosti.

7. Зв'язок спеціальної підготовленості та стану біоенергетики фрутболістів 13-14 років з типологічними властивостями центральної нервової системи / В. С. Лизогуб, В.О.Пустовалов, В. О. Супрунович, Ю. В. Коваль // Слобожанський науково-спортивний вісник. - 2015. - № 1. - С. 70-74.

8. Макаренко М. В. Онтогенез психофізіологічних функцій людини / М. В. Макаренко, В. С. Лизогуб. - Черкаси : Вертикаль, 2011. - 255 с

9. Макаренко М.В.Комп'ютерна система «Діагност - 1» для визначення нейродинамічних властивостей вищої нервової діяльності / М. В. Макаренко, В.С.Лизогуб // Особливості формування та становлення психофрізіологічних функцій в онтогенезі : матеріали симп. - Черкаси, 2003. - С. 60.

10. Макаренко М. В. Основи професійного відбору військових спеціалістів та методики вивчення індивідуальних психофрізіологічних відмінностей між людьми / М. В. Макаренко. - К. : Ін-т фрізіології ім. О. О. Богомольця, 2006. - 395 с.

\section{REFERENCES}

1. Kahanets, I. (1997). Psykholohichni aspekty v menedzhmenti: TypolohiiaYunha, sotsionika, psykhoinformatyka [Psychological aspects in management: Jung's typology, socionics, psychoinformatics]. Kyiv - Ternopil: Vydavnytstvo "Mandrivets" - "Port - Royal" [in Ukrainian].

2. Prokofeva, T.N. (2005). Sotsyonyka. Algebra igeometriya chelovecheskykh vzaimootnosheniy [Algebra and geometry of human relationships]. Moscow: Izd-vo "Almaz" [in Russian].

3. Prokofeva, T.N, Prokofev, V.G., \& Devyatkin, A.S. (2008). Sotsyonika dlya professyonalov. Sotsyonichyskiye tekhnologii v pedagogike i upravleniy personalom [Socionics for professionals. Socionic technologies in pedagogy and personnel management]. Izd-vo "Almaz" [in Russian].

4. Gulenko, V.V. (1999). Strukturno-funktsyonalnaya sotsyonyka: Razrabotka metoda kombinatoriky polyarnostey [Structural and functional socionics: Development of a method of combinatorics of polarities]. Kyiv: Transport Ukrainy [in Russian].

5. Dzh. Kammerou, Barger, N., \& Kyrby, L. (2001). Vash psykhologicheskyy typ i stil raboty [Your psychological type and work style]. Moscow: Izd-vo Instituta Psykhoterapii [in Russian].

6. Typy vyshchoi nervovoi diialnosti. Retrieved from: https:// stud.com.ua/26963/meditsina/tipi_vischoyi_nervovoyi_diyalnosti

7. Lyzohub, V.S., Pustovalov, V.O., Suprunovych, V.O., \&
Koval, Yu.V. (2015). Zviazok spetsialnoi pidhotovlenosti ta stanu bioenerhetyk u futbolistiv 13-14 rokiv z typolohichnymy vlastyvostiamy tsentralnoi nervovoi systemy [The sound of special training and state of bioenergetics in football players of 13-14 years with typological features of the central nervous system]. Slobozhanskyi naukovo-sportyvnyi visnyk - Slobozhansk Scientific and Sport Bulletin, 1, 70-74 [in Ukrainian].

8. Makarenko, M.V. (2011). Ontohenez psykhofiziolohichnykh funktsii liudyny [Ontogenesis of psychophysiological functional people]. Cherkasy: Vertykal [in Ukrainian].

9. Makarenko, M.V., \& Lyzohub, V.S. (2003). Kompiuterna systema "Diahnost - 1" dlia vyznachennia neirodynamichnykh vlastyvostei vyshchoi nervovoi diialnosti [Computer system "Diagnostics - 1" for the recognition of neurodynamic features of the nervous activity]. Materialy sympoziumu "Osoblyvosti formuvannia ta stanovlennia psykhofiziolohichnykh funktsii v ontohenezi". Cherkasy [in Ukrainian].

10. Makarenko, M.V. (2006). Osnovy profesiinoho vidboru viiskovykh spetsialistiv ta metodyky vyvchennia indyvidualnykh psykhofiziolohichnykh vidminnostei miz liudmy. [Basics of professional selection of military specialists and methods of studying individual psychophysiological differences between people]. Kyiv: O.O. Bohomolets Institute of Physiology [in Ukrainian]. 